\title{
Developmental Stage Affects Nutrient Uptake by Four Snapdragon Cultivars
}

\author{
Teresa M. Hood, Harry A. Mills, and Paul A. Thomas \\ Department of Horticulture, University of Georgia, Athens, GA 30602-7273
}

Additional index words. Antirrhinum majus, fertilization, solution culture

\begin{abstract}
Nutrient uptake by 'Apache', 'Jersey City', 'Peoria', and 'Philadelphia' snapdragons (Antirrhinum majus L.) was compared at three developmental stages: Stage I, vegetative to bud initiation; Stage II, bud initiation to visible bud; and Stage III, visible bud to anthesis. Significant differences in uptake occurred between one or more developmental stages for all nutrients tested: $\mathrm{NO}_{3}^{-} \mathrm{N}, \mathrm{NH}_{4}^{+}-\mathrm{NB}, \mathrm{Ca}, \mathrm{Cu}, \mathrm{Fe}, \mathrm{K}, \mathrm{Mg}, \mathrm{Mn}, \mathrm{Mo}, \mathrm{P}$, and $\mathrm{Zn}$. Uptake of most of the nutrients increased or remained high during Stage III. These results indicate that the current cultural practice of stopping fertilization at bud elongation should be reexamined. Differences in uptake between cultivars were found only for $\mathrm{NO}_{3}^{-}-\mathrm{N}$,as uptake by 'Apache' was significantly higher than uptake by 'Philadelphia'.
\end{abstract}

Resurgence in the popularity of snapdragons as a commercial cut flower has resulted in their increased production, especially in the southern United States. The importance of developmental stage in relation to nutritional requirements has not been investigated. Current nutritional guidelines for $\mathrm{N}$ and $\mathrm{K}$ are based on early studies with inbred and hybrid snapdragons. These studies recommend frequent fertilization in the low to medium range (100 to $200 \mathrm{mg}$.liter $)^{-1}$ ), with $\mathrm{NO}_{3}^{-}$as the recommended $\mathrm{N}$ form. These guidelines also suggest reducing fertility levels for summer crops and stopping fertilization at bud elongation (Haney, 1961; Harthun, 1991; Rogers, 1992; Sanderson, 1975). Previous research has focused primarily on the importance of $\mathrm{N}$ and $\mathrm{B}$ and not the effects of other macro- and micronutrients (Furuta, 1960; Hedley et al., 1977). The objective of this study was to determine the effect of developmental stage on the uptake of 12 essential nutrients by four snapdragon cultivars used for cut-flower production.

Four Group II cultivar-Apache, Jersey City, Peoria, and Philadelphia - were grown in solution culture under winter greenhouse conditions in Athens, Ga. (lat. $34^{\circ} \mathrm{N}$ ). After germinating in vermiculite, 5-week-old seedlings were transferred to aerated 15 -liter solution-culture pots in December. Average leaf count was 6.0 and height was $4.5 \mathrm{~cm}$ per plant. The experiment consisted of 20 pots arranged in a randomized complete-block design on a greenhouse bench. There were five replications, each replication consisted of four pots, and each pot contained three plants of one cultivar. The greenhouse air averaged $22.5 \mathrm{C}$ day and $14.5 \mathrm{C}$ night. Daily irradiance was recorded using a quantum sensor (LI-COR, Lincoln, Neb.) and greenhouse weather station (Q-Com, Irvine, Calif.). Total daily irradiance averaged $12.2 \mathrm{~mol} \cdot \mathrm{m}^{-2} \cdot$ day $^{-1}$ under a

\footnotetext{
Received for publication 1 Feb. 1993. Accepted for publication 8 May 1993. The cost of publishing this paper was defrayed in part by the payment of page charges. Under postal regulations, this paper therefore must be hereby marked advertisement solely to indicate this fact.
}

10-h photoperiod. Plants were grown in deionized water for 2 days, then placed in 14 liters of 1/4-strength modified Hoagland's solution. After 5 days, plants were placed in full-strength modified Hoagland's solution [similar to one used by Oertli (1970)], which contained (in milligrams per liter) $150 \mathrm{~N}\left(5 \mathbb{Q U H}_{4}^{+}-\mathrm{N}: 50\right.$ $\left.\mathrm{NO}_{3}^{-}-\mathrm{N}\right), \quad 20 \mathrm{P}, 100 \mathrm{~K}, 113 \mathrm{Ca}, 30 \mathrm{Mg}, 157 \mathrm{~S}$, $10 \mathrm{Cl}, 5 \mathrm{Fe}, 0.5 \mathrm{~B}, 0.5 \mathrm{Mn}, 0.05 \mathrm{Zn}, 0.02 \mathrm{Cu}$, and $0.01 \mathrm{Mo}$.

Transpiration losses were recorded and replaced daily with deionized water. Solution $\mathrm{pH}$ was monitored daily; initial $\mathrm{pH}$ was 6.2. Nutrient solutions were changed every 7 days for the first 5 weeks; thereafter, solutions were changed every 5 days to maintain a weekly variation of $<2 \mathrm{pH}$ units. Nutrient uptake was determined at each solution change as the difference between initial and final concentrations of ions in solution. Nitrate $\mathrm{N}$ and $\mathbf{N H}_{4}^{+}-\mathbf{N}$ concentrations were determined using a continuous-flow $\mathrm{N}$ analyzer (Lachat Autoanalyzer, Milwaukee). Boron, $\mathrm{Ca}, \mathrm{Cu}, \mathrm{Fe}, \mathrm{K}, \mathrm{Mg}, \mathrm{Mn}$, $\mathrm{Mo}, \mathrm{P}$, and $\mathrm{Zn}$ concentrations were determined using an inductively coupled Ar plasma emission spectrophotometer (Jarrell-Ash, Franklin, Mass.). After harvest, plants were dried in a $70 \mathrm{C}$ forced-air oven and ground in a Wiley mill to pass through a 20-mesh screen to determine Kjeldahl N (Isaac and Johnson, 1976) and $\mathrm{NO}_{3}^{-}-\mathrm{N}$ using a continuous-flow $\mathrm{N}$ analyzer.

Three developmental stages of snapdragons were defined to examine nutrient uptake in this study. Stage I covered vegetative growth to bud initiation. Stage II included bud initiation to visible bud. Bud initiation in snapdragons occurs 5 to 7 days before visible bud (Edwards and Goldenberg, 1976; Rabinowitch et al., 1976). Based on this observation, bud initiation dates for this experiment were calculated as occurring 6 days before visible bud. Flower buds that were $22.0 \mathrm{~mm}$ in diameter were considered visible. Stage III was considered between visible bud and anthesis. Plants were harvested at the end of Stage III, 12 weeks after the study began. These stages are based on those outlined by Edwards and Goldenberg (1976), with the addition of the visible bud stage as a delineator. Visible bud or bud growth often is used as a guide in snapdragon fertilizer recommendations (Duffett, 1960; Haney, 1961; Harthun, 1991). Visible bud and anthesis dates were recorded for each plant and bud initiation dates were calculated as described above.

Differences in nutrient uptake at the three developmental stages were analyzed for all cultivars using a general linear model (GLM) procedure and Duncan's multiple range test. Differences in cumulative uptake between cultivars were analyzed using linear regression and a GLM procedure.

Significant differences in uptake for all nutrients occurred between two of the three developmental stages. Uptake of $\mathrm{K}, \mathrm{Mg}, \mathrm{Fe}$, $\mathrm{Mn}, \mathrm{Mo}$, and $\mathrm{Zn}$ was significantly different at all three developmental stages (Table 1).

Nitrate $\mathrm{N}$ and $\mathbf{N H}_{4}^{+}-\mathbf{N}$ uptake was significantly higher during Stage III than during Stages I and II, during which it was similar (Table 1). Only $6 \%$ of total tissue $\mathrm{N}$ was $\mathrm{NO}_{3}^{-}-\mathrm{N}$, a result indicating that most $\mathrm{NO}_{3}^{-}-\mathrm{N}$ taken up by plants was used rather than stored (data not shown). Studies with marigold (Tagetes erecta L.) also found that the highest $\mathrm{N}$ uptake occurred in later growth stages (Tolman et al., 1990), but $\mathrm{N}$ uptake by chrysanthemums [Dendranthema xgrandiflorium (Ramat.) Kitamura] was found to decrease as plants aged (Willits et al., 1992).

Nitrate $\mathrm{N}$ uptake was higher than $\mathrm{NH}_{4}^{+}-\mathrm{N}$ uptake in all three developmental stages (Table 1). Ammonium used as the sole $\mathrm{N}$ source reduces snapdragon dry weight and detrimentally accelerates their life cycle (Bastida et al., 1988). Also, current fertilizer guidelines recommend using $\mathrm{NO}_{3}^{-}$rather than $\mathrm{NH}_{4}^{+}$for snapdragons (Harthun, 1991). The greatest difference in uptake of $\quad \mathrm{NO}_{3}^{-}-\mathrm{N}$ and $\mathrm{NH}_{4}^{+}-\mathrm{N} \quad$ occurred at Stage I: at this stage, the ratio was higher

Table 1. Mean uptake of elements ${ }^{2}$ from modified Hoagland's nutrient solution by 'Apache', 'Jersey City', 'Peoria', and 'Philadelphia' snapdragon at three developmental stages: Stage I, vegetative to bud initiation; Stage II, bud initiation to visible bud; Stage III, visible bud to anthesis.

\begin{tabular}{lccc}
\hline & \multicolumn{3}{c}{ Elemental uptake } \\
\cline { 2 - 4 } & \multicolumn{3}{c}{ Stage } \\
\cline { 2 - 4 } Element & 1 & 2 \\
& \multicolumn{3}{c}{ mg/plant } \\
$\mathrm{NO}_{3}^{-}-\mathrm{N}$ & $61.2 \mathrm{a}^{\mathrm{y}}$ & $51.7 \mathrm{a}$ & $92.8 \mathrm{~b}$ \\
$\mathrm{NH}_{4}^{+}-\mathrm{N}$ & $30.4 \mathrm{a}$ & $33.4 \mathrm{a}$ & $52.7 \mathrm{~b}$ \\
$\mathrm{P}$ & $13.3 \mathrm{a}$ & $8.1 \mathrm{~b}$ & $14.8 \mathrm{a}$ \\
$\mathrm{K}$ & $32.4 \mathrm{a}$ & $5.2 \mathrm{~b}$ & $55.4 \mathrm{c}$ \\
$\mathrm{Ca}$ & $27.0 \mathrm{a}$ & $3.1 \mathrm{~b}$ & $26.1 \mathrm{a}$ \\
$\mathrm{Mg}$ & $6.7 \mathrm{a}$ & $1.2 \mathrm{~b}$ & $10.8 \mathrm{c}$ \\
& $\mu \mathrm{ag} /$ plant & \\
$\mathrm{B}$ & $32.2 \mathrm{a}$ & $5.6 \mathrm{a}$ & $193 \mathrm{~b}$ \\
$\mathrm{Cu}$ & $47.6 \mathrm{a}$ & $14.0 \mathrm{~b}$ & $21.0 \mathrm{~b}$ \\
$\mathrm{Fe}$ & $3850 \mathrm{a}$ & $5048 \mathrm{~b}$ & $6222 \mathrm{c}$ \\
$\mathrm{Mn}$ & $71.4 \mathrm{a}$ & $19.6 \mathrm{~b}$ & $183.4 \mathrm{c}$ \\
$\mathrm{Mo}$ & $15.4 \mathrm{a}$ & $35.0 \mathrm{~b}$ & $0.0 \mathrm{c}$ \\
$\mathrm{Zn}$ & $364 \mathrm{a}$ & $146 \mathrm{~b}$ & $127 \mathrm{c}$ \\
\hline
\end{tabular}

${ }^{2}$ Values based on mean uptake by 15 plants of each cultivar, each in 14 liters of nutrient solution. 'Mean separation within rows by Duncan's multiple range test, $\alpha=0.05$. 
than $2 \mathrm{NO}_{3}^{-}-\mathrm{N}: 1 \mathrm{NH}_{4}^{+}-\mathrm{N}$ (Table 1). These findings agree with Haney's (1961) statement that snapdragons, especially in the early growth stages, preferentially absorid $\mathrm{BO}_{3}^{-}-\mathrm{N}$ to $\mathrm{NH}_{4}^{+}-\mathrm{N}$.

Phosphorus uptake during Stage II was $39 \%$ lower than uptake at Stage I, but during Stage III, uptake increased $81 \%$ over that during Stage IL Studies with chrysanthemums have found similar fluctuations in P uptake as plants developed, with increases in uptake occurring 10 days after visible bud and continuing until inflorescence color was evident (Boodley and Meyer, 1965; Willets et al., 1992). Fertilizer recommendations state that snapdragon seedlings may absorb enough $\mathrm{P}$ from one early application to complete their life cycle without further P applications (Haney, 1961). However, results of this study indicate that $\mathrm{P}$ uptake at Stage III is as great as uptake at Stage I, a result indicating that additional $\mathrm{P}$ applications may be necessary.

Potassium uptake dropped during Stage II but was significantly different at all three stages (Table 1). Uptake during Stage II was $84 \%$ lower than during Stage I; uptake then increased at Stage III to $70 \%$ higher than at Stage I. Research with chrysanthemum indicated that $\mathrm{K}$ uptake generally increased with overall plant age, but increased the least in the period immediately following visible bud (Boodley and Meyer, 1965). Inflorescence count and color intensity in chrysanthemums (Joiner and Smith, 1961) and roses (Rosa hybrida L.) (Woodson and Boodley, 1982) were affected detrimentally by low K levels.

Potassium uptake in other species increases with increasing light and temperature (Gislerød and Adams, 1983). Calcium uptake in many species is affected by transpiration rate. Light and temperature may change transpiration rates in snapdragons (Rutland, 1972). Mean uptake of $\mathrm{K}, \mathrm{Ca}, \mathrm{NO}_{3}^{-}-\mathrm{N}, \mathrm{NH}_{4}^{+}-\mathrm{N}, \mathrm{P}, \mathrm{Mg}, \mathrm{B}, \mathrm{Cu}, \mathrm{Fe}$, $\mathrm{Mn}, \mathrm{Mo}$, and $\mathrm{Zn}$ was compared to average daily high and low temperatures and average daily irradiance, but no patterns indicating influences of temperature and light on nutrient uptake were found for the snapdragon cultivars in this study.

Calcium uptake during Stage II was reduced $89 \%$ and $88 \%$ below uptake at Stages I and III, respectively (Table 1). Boodley and Meyer (1965) found a similar drop in $\mathrm{Ca}$ uptake before and during the visible bud stage in chrysanthemums. A constant supply of medium to high levels of $\mathrm{Ca}$ was recommended for snapdragons, primarily for healthy roots (Haney, 1961), but these results suggest that a constant high level of $\mathrm{Ca}$ is not necessary.

Similar to K uptake, Mg uptake dropped during Stage II but was significantly different at all three stages (Table 1). Magnesium uptake at Stage II dropped to $83 \%$ below uptake at Stage I and then increased during Stage III to $62 \%$ higher than that at Stage I. These results contradict fertilizer recommendations that state that snapdragons require a constant supply of high levels of Mg (Haney, 1961; Rogers, 1992).

Boron deficiency in snapdragons causes flower bud abortion and malformed florets
(Mastalerz, 1957). Boron uptake by all cultivars was significantly higher during Stage III, with no difference in uptake between Stages I and II. Uptake at Stage III was 6 times higher than uptake at Stage I (Table 1). All plants exhibited normal growth with no evidence of bud abortion or flower distortion.

Similar to uptake of $\quad \mathrm{NO}_{3}^{-}-\mathrm{N}, \mathbf{N H}_{4}^{+}-\mathbf{N}$ and $\mathrm{Ca}$, mean $\mathrm{Cu}$ uptake at Stage I was significantly higher than uptake during Stages II and III, when uptake was $71 \%$ and $56 \%$ lower, respectively (Table 1 ).

Uptake of Fe, Mn, Mo, and Zn was significantly different at all three stages (Table 1). Iron uptake increased with each succeeding stage. Uptake at Stage II was $31 \%$ higher than at Stage I, and at Stage III it was $23 \%$ higher than at Stage II. Because Fe is not translocated readily, the health of young tissues depends on a continuous Fe supply. Iron uptake in this study steadily increased as plants increased in

Table 2. Mean uptake of $\mathrm{NO}_{3}^{-}-\mathrm{N}$ and $\mathrm{NH}_{4}^{+}-\mathrm{N}$ from modified Hoagland's solution containing 150 mg N $\left(50 \mathrm{NO}_{3}^{-} \mathrm{N}: 50 \mathrm{NH}_{4}^{+}-\mathrm{N}\right) /$ liter by four snapdragon cultivars.

\begin{tabular}{lcc}
\hline & \multicolumn{2}{c}{ Mean uptake $^{z}$} \\
\cline { 2 - 3 } Cultivar & \multicolumn{2}{c}{ Element } \\
\cline { 2 - 3 } & $\mathrm{NO}_{3}^{-}-\mathrm{N}$ & $\mathrm{NH}_{4}^{+}-\mathrm{N}$ \\
Apache & $m g /$ plant & \\
Jersey City & $91.0 \mathrm{a}^{y}$ & $41.0 \mathrm{a}$ \\
Peoria & $82.2 \mathrm{ab}$ & $38.9 \mathrm{a}$ \\
Philadelphia & $54.5 \mathrm{ab}$ & $37.9 \mathrm{a}$ \\
& $46.8 \mathrm{~b}$ & $37.7 \mathrm{a}$
\end{tabular}

${ }^{2}$ Values based on mean uptake by 15 plants, each in 14 liters of nutrient solution.

'Mean separation within columns by Duncan's multiple range test, $\alpha=0.05$. weight, a result indicating a need for continuous Fe. Similar to uptake of $\mathrm{K}$ and $\mathrm{Mg}, \mathrm{Mn}$ uptake also dropped at Stage II and increased again during Stage III (Table 1). Uptake at Stage II was $73 \%$ lower than that at Stage I and, at Stage III, was $157 \%$ higher than that at Stage I. Molybdenum uptake also was significantly different at each stage, with the highest uptake occurring during Stage II (Table 1). Uptake at Stage II increased $127 \%$ over that at Stage I. Although $\quad \mathrm{NO}_{3}^{-}-\mathrm{N}$ uptake was highest during Stage III, no Mo uptake occurred during this stage. Zinc uptake significantly decreased with each succeeding stage (Table 1). Uptake at Stage II was $60 \%$ lower than uptake at Stage I, and uptake at Stage III was $12 \%$ lower than uptake at Stage II.

Significant differences in uptake between cultivars occurred only foNO $\mathrm{N}_{3}^{-} \mathrm{N}$. Mean $\mathrm{NO}_{3}^{-}-\mathrm{N}$ uptake by 'Apache' plants was 2 times higher than uptake by 'Philadelphia' plants (Table 2). Previous studies have shown that snapdragon cultivars differ in growth response to changing $\mathrm{N}$ concentration in the nutrient medium (Arthur and Hedley, 1976). No significant stage $\times$ cultivar interactions were found for $\mathrm{NO}_{3}^{-}-\mathrm{N}$ uptake; cultivars differed in mean $\mathrm{NO}_{3}^{-} \mathrm{N} \quad$ uptake during all three developmental stages (Fig. 1). No differences in mean $\quad \mathrm{NH}_{4}^{+}-\mathbf{N}$ uptake between the four cultivars were found (Table 2), but a significant $(P \leq 0.05)$ stage $\times$ cultivar interaction effect was found (data not shown). Cultivars differed more $\mathrm{iNH}_{4}^{+}-\mathrm{N}$ uptake during Stage III than during the previous two developmental stages (Fig. 2). All four cultivars preferentially absorbed $\mathrm{NO}_{3}^{-}-\mathrm{N}$ over $\mathbf{N H}_{4}^{+}-\mathbf{N}$ (Table 2).

Nutrient uptake by all snapdragon cultivars tested varied during plant development.

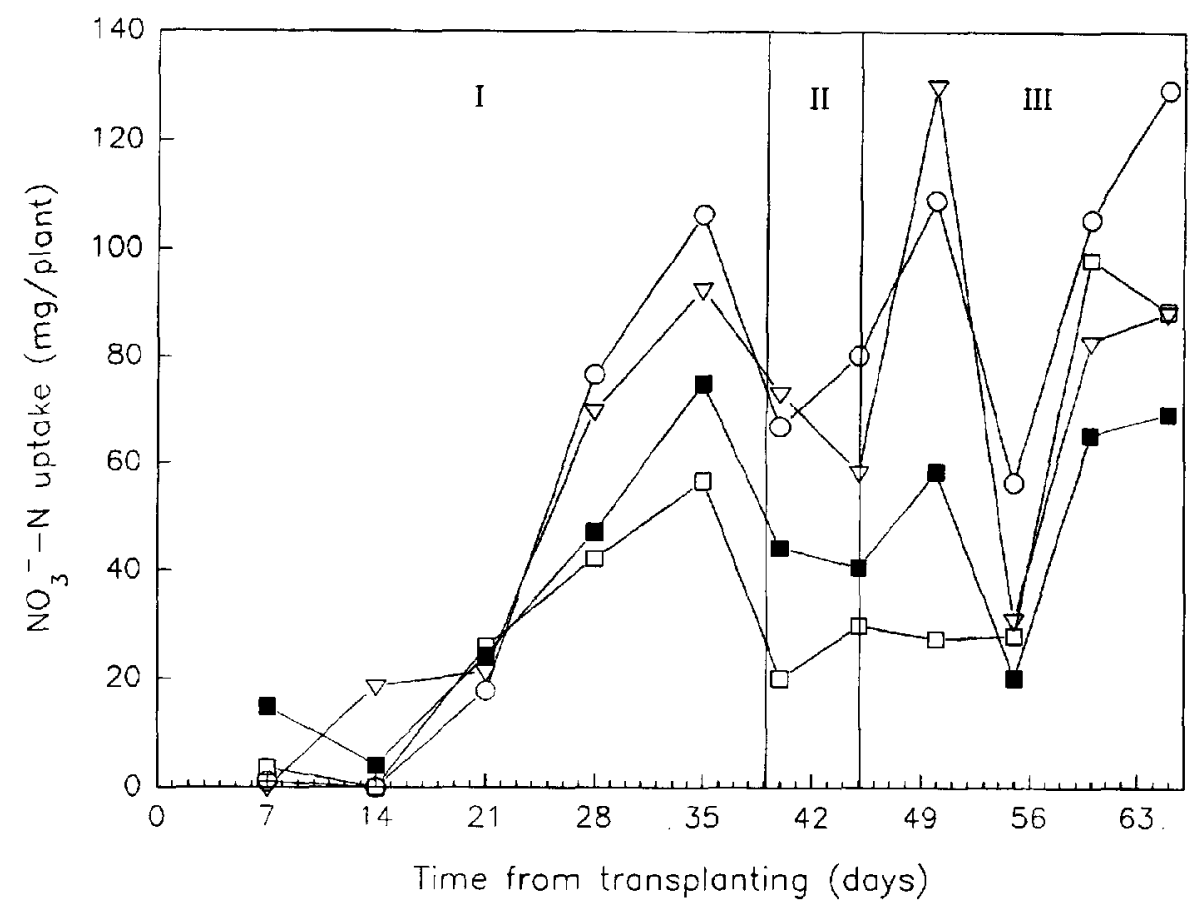

Fig. 1. Mean uptake of $\mathrm{NO}_{3}^{-}-\mathrm{N}$ from modified Hoagland's solution by four snapdragon cultivars-Apache $(O)$, Jersey City ( $\Delta$ ), Peoria ( $\square$ ), and Philadelphia (D)_at three devclopmental stagcs: I, vcgetative to bud initiation; II, bud initiation to visible bud; and III, visible bud to anthesis. Points represent mean uptake per plant by 15 plants, each in 14 liters of nutrient solution. 


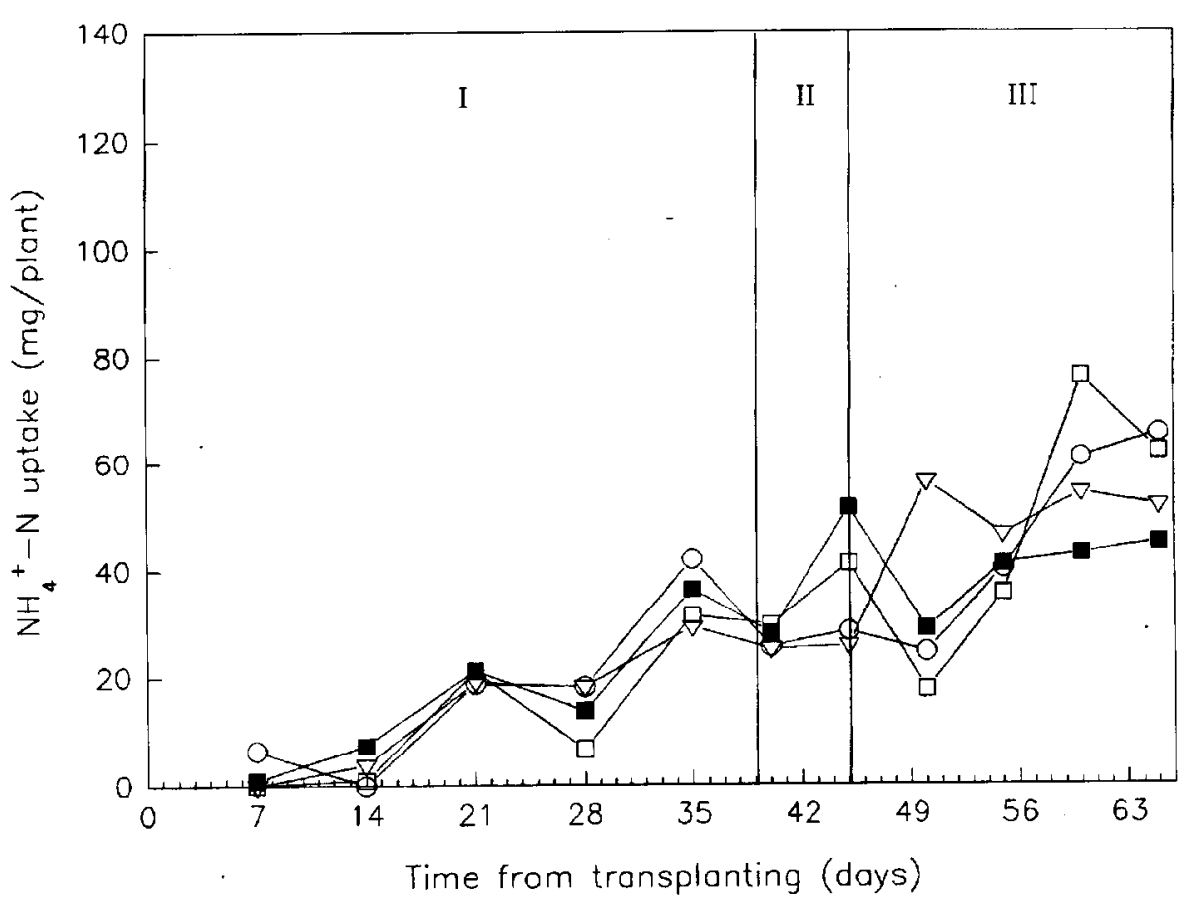

Fig. 2. Mean uptake of $\mathrm{NH}_{4}^{+}-\mathrm{N}$ from modified Hoagland's solution by four snapdragon cultivars-Apache $(O)$, Jersey City $(\Delta)$, Peoria $(\square)$, and Philadelphia ( $(\square)$-at three developmental stages: I, vegetative to bud initiation; II, bud initiation to visible bud; and III, visible bud to anthesis. Points represent mean uptake per plant by 15 plants, each in 14 liters of nutrient solution.

Copper, Mo, and $\mathrm{Zn}$ were taken up in the highest amounts during early developmental stages, a result emphasizing the importance of early availability of these nutrients for these snapdragon cultivars. However, for most nutrients $\left(\mathrm{NO}_{3}^{-}-\mathbf{N}, \mathrm{NH}_{4}^{+}-\mathbf{N}, \mathrm{B}, \mathrm{Ca}, \mathrm{Fe}, \mathrm{K}, \mathrm{Mg}, \mathrm{Mn}\right.$, and $\mathrm{P}$ ), uptake remained high or significantly increased during the stage following visible bud (Stage III), a time when many growers stop all fertilization. Snapdragons are prone to postharvest shatter and tip breakage and remain a local crop because of shipping problems (Harthun, 1991; Rogers, 1992). Results of this study suggest that growers may need to continue fertilization past the bud elongation stage, paying special attention to the effect of continued fertilization on postharvest problems currently encountered with snapdragons.
Furuta, T. 1960. Test boron deficiency in snapdragons at Auburn. Florist's Rev. 126(3244):25.

Gislerød, H.R. and P. Adams. 1983. Diurnal variations in the oxygen content and acid requirement of recirculating nutrient solutions and in the uptake of water and potassium by cucumber and tomato plants. Scientia Hort. 21:311-321.

Haney, W.J. 1961. Snapdragon culture. Michigan Florist 366:25-26, 29.

Harthun, E. 1991. Snapdragon, p. 765-770. In: V. Ball (ed.). Ball red book. 15th ed. Ball Publishers, West Chicago, Ill.

Hedley, C.L., A.E. Arthur, and H.D. Rabinowitch. 1977. The effects of nitrogen level on the performance of Antirrhinum cultivars grown in greenhouse conditions. Euphytica 26:755-760.

Isaac, R.A. and W.C. Johnson. 1976. Determination of total nitrogen in plant tissue, using a block digester. J. Assn. Offic. Anal.. Chemists 59:98-100.

Joiner, J.N. and T.C. Smith. 1961. Effects of nitrogen and potassium levels on the growth, flowering response and foliar composition of Chrysanthemum morfolium 'Bluechip'. Proc. Amer. Soc. Hort. Sci. 80:571-580.

Mastalerz, J.W. 1957. Boron deficiency of snapdragons. Pennsylvania Flower Grower's Bul. 75:3-6.

Oertli, J.J. 1970. Nutrient disorders in snapdragons. Florists' Rev. 146(3773):20-21.

Rabinowitch, H.D., C.L. Hedley, and A.E. Arthur. 1976. Variation in budding and flowering-time of commercial cultivars of Antirrhinum majus. Scientia Hort. 5:287-291.

Rogers, M.N. 1992. Snapdragons, p. 93-112. In: R.A. Larson (ed.). Introduction to floriculture. 2nd ed. Academic, New York.

Rutland, R.F. 1972. Transpiration of Antirrhinum majus L. in relation to radiant energy in the greenhouse. HortScience 7:39-40.

Arthur, A.E. and C.L. Hedley. 1976. The effects of nitrogen on five varieties of Antirrhinum majus. Ann. Bot. 41:627-636.

Bastida, J., J.M. Llabres, F. Viladomat, R.M. Cusido, and C. Codina. 1988. Free amino acids and alkaloid content in snapdragon plants grown with nitrate, urea or ammonium nutrition. J. Plant Nutr. 11(1):1-15.

Boodley, J.W. and M. Meyer, Jr. 1965. The nutrient content of Bonnaffon Deluxe chrysanthemums from juvenile to mature growth. Proc. Amer. Soc. Hort. Sci. 87:472-478.

Duffett, W.E. 1960. Culture of greenhouse snapdragons. Ohio Florist's Assn. Bul. 466:5-7.

Edwards, K.J.R. and J.B. Goldenberg. 1976. A temperature effect on the expression of genotypic differences in flowering induction in $\mathrm{An}$ tirrhinum majus. Ann. Bot. 40: 1277-1283.
Sanderson, K.C. 1975. A crop to meet the energy crisis-Snapdragon Part 3, fertilization, watering, temperature, light and photoperiod. Florists' Rev. 156(4038):17, 59-61.

Tolman, D.A., A.X. Niemiera, and R.D. Wright. 1990. Influence of plant age on nutrient absorption for marigold seedlings. HortScience 25:1612-1613.

Willits, D.H., P.V. Nelson, M.M. Peet, M.A. Depa, and J.S. Kuehny. 1992. Modeling nutient uptake in chrysanthemum as a function of growth rate. J. Amer. Soc. Hort. Sci. 117:769-774.

Woodson, W.R. and J.W. Boodley. 1982. Effects of nitrogen form and potassium concentration on growth, flowering, and nitrogen utilization of greenhouse roses. J. Amer. Soc. Hort. Sci. 107:275-278. 